\title{
Adopting Work-style Reforms, Promoting the Inclusive Workplace: Japan's Strategies on the Diversifying Labor Market
}

\author{
Firman Budianto \\ Research Center for Area Studies, the Indonesian Institute of Sciences (LIPI) \\ Email: firman.budianto@lipi.go.id
}

\begin{abstract}
As a response to the diversifying labor market, the government of Japan has released a set of policies to foster productivity and increase participation of not only women but also seniors, people with disabilities, and foreigners in the country's job market. However, the literature on the diversification of Japan's labor force has paid little attention to the Japanese government's perspectives on this issue. This qualitative study, therefore, examines the current Japanese government's strategies in regards with the changing domestic labor market and workplace through critical analyses of the government's policies and publications. This study observed that the government of Japan has set out to adopt work-style reforms and promote an inclusive workplace for everyone. These two key policies should address the inequality and the work-life balance issues as the core obstacle in Japan's business practices. This present study suggests that fundamental reforms in the way Japanese people work might pave the way to solving the country's economic and sociocultural challenges that, to some extent, are rooted in the structural problems in the workplace.
\end{abstract}

Keywords: Diversification of labor market, Inclusive workplace, Japan's labor market, Work-style reforms

\section{Introduction}

December 8, 2018 marked a major decision in the Japanese immigration legislation as on that day, Japanese lawmakers finally approved a new policy proposed by the government, paving the way for a new visa category that allows more foreign workers to come, live and work in Japan (see: CNBC, 2018; Nikkei Asian Review, 2018; The Associated Press, 2018; The Wall Street Journal, 2018). Similar with the assessment of highly skilled workers visa that is based on point systems (MOJ, 2018), this new visa category, later known as Specified Skilled Worker Visa or Tokutei Ginō, also requires examination of the foreign workers' skillset, including certain degree of Japanese language proficiency and the specified skills for each industry. This new visa policy is closely related to what is taking place in contemporary Japan. It, first, indicates the government's commitment to take decisive action in facing the current change in the domestic labor market. According to MHLW (2018), the job opening-to-applicant ratio in 2017 hit 1.59 , the highest ratio since 1974 , while the unemployment rate falls to $2.4 \%$, the lowest rate since 1995. Second, as one of the attempts to bring in more skilled foreign workers to Japan, the policy reflects the government's larger plan to keep the country's economic growth following the implementation of Abenomics policy that promotes active participation of anyone in the workforce including the foreigners.

Taking into account the situations, it could be expected that more and more 
foreign workers would come to Japan and consequently the participation of foreign nationals in Japanese workplace would also increase in the near future. However, numerous studies have demonstrated that foreigners in Japanese businesses, both the less-skilled (e.g., Nakamura, 2010) and the highly-skilled workers (e.g. Moriya, 2012; Oishi, 2012) are facing work-related limitations. While discussing the challenges in the Japanese corporations, these studies, on the one hand, mainly urge stakeholders to implement structural reforms within the Japanese workplace and suggest formulating a policy that promotes an inclusive workplace for everyone, including non-Japanese nationals. On the other hand, these studies pay little attention to the Japanese government's perspectives and current policies in this regard.

This study, therefore, attempts to contribute to this gap and focuses on examining recent government strategies and policies regarding the changing labor market and the increasing participation of foreigners in the Japanese workplace through the analyses of government publications. This topic is increasingly significant considering that non-Japanese nationals will soon become a substantial part of Japan's labor market (Liu-Farrer, 2011). For that reason, the research on how the government of a country that is currently facing a changing labor market deals with the increasing foreign workers and the emerging labor issue is needed and increasingly significant.

\section{Methods}

This study employs qualitative method with a critical analysis approach to investigate how the Japanese government responds to the emerging diversification in its domestic labor market. The primary data was collected from document and content analysis of the Government of Japan's official publications regarding the aimed topics from 2016 to 2018.

This present study, in particular, was carried out in three stages. The first stage is literature review, where previous studies on Japanese workplace were carefully examined. The next stage is data collection, followed by data analysis.

In the data collection stage, publicly available materials were used as the primary data. The data was accessed from the Japanese government official websites, in both original Japanese and official English translations, to represent the Japanese side. The final stage is data analysis. The data collected from document and content analysis were inter-textually analyzed to see the relationship between the policies on diversification of Japan's labor market with the academic literature available on the topic.

\section{Result and Discussion}

The Government of Japan's comprehensive plan on its diversifying labor market is seen in this study as inseparable from the economic revitalization attempts reflected on the Abenomics policy. The Abenomics, a signature policy by PM Abe launched in 2012, is initially started as a comprehensive policy package aimed at reviving the Japanese economy. The policy, however, has evolved into a broader blueprint for progrowth socioeconomic change (JapanGov, 2019). One of Abenomics' key visions related to the country's changing labor 
market is fostering productivity of individuals and society by emphasizing the people as the key actor in economic activities. The government promotes three key actions on this aim, i.e. (1) work-style reform, (2) human resources development, and (3) allowing participation of the women, the seniors, and the expatriates.

Besides Abenomics, this study found that the Government of Japan has also released other three crucial strategies related to the 'people', i.e., the "Plan for Dynamic Engagement of All Citizens" in June 2016; the "New Economic Policy Package" in December 2017, and the "Future Investment Strategy" in June 2018. The first policy is rooted in the concept of 'ichioku sōkatsuyaku', a concept that cherishes every citizen's life, which aims to promote a society where all citizens can participate and play an active role (Prime Minister of Japan and His Cabinet, 2016). In the later policies, the government is taking a further step and planning to improve productivity by promoting inclusiveness and flexibility in the workplace that allows the increasing participation of four groups of people: the women, the elderly, the disabled, and the foreigners (Prime Minister of Japan and His Cabinet, 2018).

Those set of policies are seen in this study to indicate the government's strategies regarding the sociocultural change due to the aging population and the emerging diversified domestic labor market. Among those strategies, the most critical actions that the government needs to implement promptly could be categorized into two, i.e. (1) to reform the old-fashioned work-style and (2) to promote inclusiveness in the workplace regardless of people's nationality, race, gender, and religious belief. The following section explicitly analyzes these two categories and discusses the challenges that come with them.

\subsection{Adopting Work-style Reforms}

According to the government of Japan, work-style reform focuses on the following aspects (JapanGov, 2019; Prime Minister of Japan and His Cabinet, 2016). Firstly, it aims to improve working conditions of non-regular workers by eliminating irrational gaps in the working conditions and unfair evaluation between regular and non-regular workers. According to Asao (2011), the central problem between regular and non-regular workers in Japan lies in the unequal treatment between those two groups of workers. In Japan, the term non-regular workers refer to part-time workers, temporary and contract workers, including dispatch workers. These nonregular employees frequently get lower wages while having the same workload and responsibility compared to the regular ones. The other issues are mainly about the employment instability and the opportunity of converting to regular employees. According to JILPT survey in 2010 (cited in Asao, 2011), the lack of the opportunity to work as a regular employee is the most reason why contract and dispatch workers often end up in non-regular employment.

Secondly, as stated in the Japanese government plan, the work-reform intends to reduce the practices of long working hours. This "long working hours" issue is inseparable from work-life balance problem in Japanese companies that has been widely discussed in most studies on Japanese workplace (e.g. Moriya, 2012; Oishi, 2012) and is one of the reasons why some 
Japanese people choose to quit the job and even migrate to other countries (Nagatomo, 2014). Oishi (2012), for instance, argues that service overtime is common practice among small medium-sized companies and the employees are often not paid for those hours. Another instance, as argued by Nagatomo (2014), is the Japanese company's unwritten norm that it is uncommon for junior staff to leave office before their supervisors. As a result, they end up working overtime. Furthermore, this work-life balance issue leads to the lack of family time and time for childcare, partly explaining why Japan has a low number of birthrate and the participation of women in the workplace.

Thirdly, the work-style reform promotes a flexible working style. Even though this is closely related to the above work-life balance-related issue, flexible work could be considered relatively recent in the discourse around the Japanese workplace. According to JapanGov (2019), with the latest proposed regulation, the government will "promote teleworking, side jobs and those who wish to take on multiple jobs with a variety of policy measures [...]". This flexible work-style would be one of the most appealing solutions proposed by the government for the overall work-related problems, but in the same time, is also the most challenging to implement as it must challenge the existing business practices.

\subsection{Promoting Inclusive Workplace}

As the labor market changes, the composition of the worker's shifts means the diversification in labor structure is currently taking place in the Japanese workplace and economy. This study observed that the diversifying labor structure is indicated by the increasing participation of 'new' actors that have not been in the eyes of the Japanese government. Given the change in the labor market and structure, the government has started to strongly encourage four groups to actively participate in the workplace, i.e., the women, the seniors, the people with disability, and the foreigners. Among people in these groups, the women and the foreigners are previously known to face many structural limitations to enter the labor market.

According to a survey conducted by the Ministry of Internal Affairs and Communications of Japan (2017), $75.2 \%$ of Japanese women aged 30 to 34 years are currently in employment, and the number increased by $11.2 \%$ from 2007 . The period has also seen an increase in the age group of 35 to 39 and 40 to 44 , with $9.1 \%$ and $5 \%$ increase respectively, making the oncesharp $M$ shape in the Japan's female workforce participation graph has softened. The government also support to increase the proportion of female employees in private company's top management position by $30 \%$ in 2020, compared to $6.9 \%$ in 2012 and 9.3\% in 2016 (Gender Equality Bureau of Japan, 2017). The working women frequently have no choice but to quit the job after having a child. Therefore, this policy on the inclusive workplace is beneficial, especially for career women who choose to continue to work even after having a child. Furthermore, the policy is seen in this study to pave the way for women to shine at work as intended by the government.

Besides women, the inclusive workplace policy is also crucial for foreigners, especially the skilled ones. This 


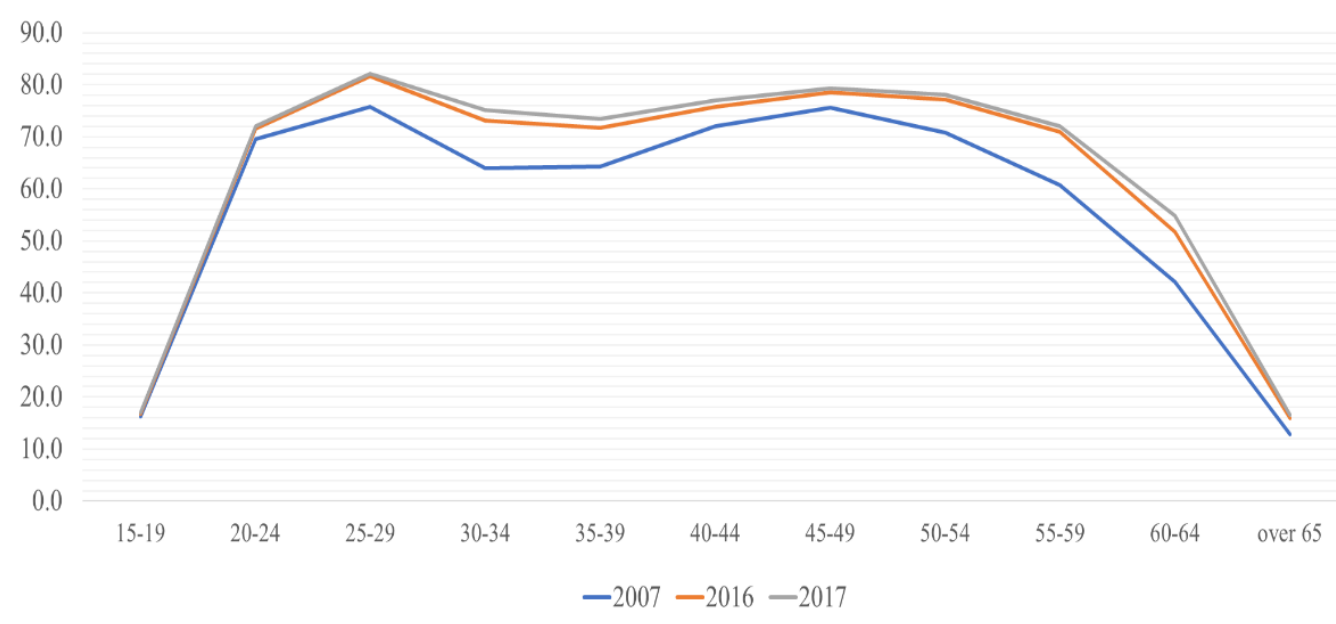

Chart 1. Female labor force participation rate

(Ministry of Internal Affairs and Communication, 2017)

group of people is a substantial part of Japan's future labor pool (Liu-Farrer, 2011), and they are playing an increasingly important role in Japanese companies. Therefore, a supportive and inclusive work environment is indispensable for them as well. Moreover, considering the government's plan to keep the door open for more and more foreign professionals to come, the promotion of inclusive workplace for foreigners should therefore take into account some aspects that differentiate the foreigners from Japanese people, such as ethnicity and cultural background, including religion, as well as structural limitations in the workplace faced by the foreign workers.

Foreign workers especially the global talents, according to (Oishi, 2012), are facing institutional and non-institutional barriers in the Japanese company that limit their settlement in Japan. She emphasizes on the importance of reforms in corporate structures and business practices of Japanese corporations. On a more micro level, Kameda (2013) argues that it is urgent to change the Japanese management style and the use of language within the company in order to achieve the 'multicultural' company, instead of only 'multinationals' company. Moreover, he also argues that the existing staffing system should be adjusted.

\subsection{The Call for Everyone to Shine at Workplace and Society}

The diversification of Japan's labor market following the economic and sociocultural changes in the country is unavoidable. This study observed that, as a response, the government of Japan had released a set of policies and strategies to foster productivity and increase participation of not only foreigners but also women, seniors, and people with disabilities in the country's job market. The strategies, firstly, indicate the government's stance to include everyone to participate in the society regardless of gender, cultural background, or nationality. Secondly, it demonstrates the government's commitment to the importance of the people as a critical aspect of economic activities 
while keeping the core idea of the SDGs to leave no one behind.

Furthermore, to realize the above strategies, the government of Japan has set out to promote work-style reform and an inclusive workplace for everyone. These two key policies should cover inequality between regular and non-regular workers and the work-life balance issue as the core problem in Japan's business practice. The idea, however, could only be achieved by cooperation with the businesses. Therefore, the revision of the "Charter of Corporate Behavior" document by Japan's business federation that includes the point of work practices reform and enhancement of workplace environments (Keidanren, 2017) indicates an excellent initial start for this challenging work-style reform.

This study, therefore, argues that promotion of inclusive workplace for everyone could only be doable by cooperation with the business world. In the recent years, the women and highly skilled foreign professionals, the two groups that have been discussed in the previous section, are the ones that are most welcomed and expected to join the labor market. The participation of women in Japan's workforce demonstrates a good sign as the participation of women in the labor market has gradually increased in the past few years (Gender Equality Bureau of Japan, 2017). The number could keep going even higher if the plans on work-style reform and inclusive workplace were successfully implemented. This study observes that inclusive workplace for women is more about equality in work opportunities and flexibility in the workplace, including career advancement and the descent worklife balance, especially for women with children.

Regarding promoting an inclusive workplace for foreign workers, the particular group of foreigners that the government prioritizes more is only the highly skilled ones. For that reason, the less skilled ones have not yet received much attention. The concept of inclusive workplace for skilled foreign workers is seen in this study to be quite different from the working women. For the foreign professionals, the inclusive workplace means a supportive working environment that allows them to make use of their foreignness instead of making the foreignness as a barrier to work in Japanese corporations, so that the idea of "a multicultural company (Kameda, 2013)" within the Japanese company could be realized. The government, similarly, needs to prepare and formulate a particular policy regarding the coming of more foreign workers following the implementation of the new working visa category by taking into account not only their participation in Japan's labor market but also their participation in Japanese society in general.

\section{Conclusions}

Overall, the policies and strategies on the changing labor market and the increasing participation of foreigners in Japan's labor market could be found in the government's strategies and policies. They include the adoption of work-style reforms and the promotion of inclusive workplace. This study argues that these two key strategies align with the existing studies that have suggested structural reforms within the Japanese workplace. However, all these policies and strategies could only be 
implemented with the support and coordination of all stakeholders, especially the Japanese corporations. Finally, this study suggests that Japan's economic and sociocultural problems are to some extent rooted in the structural problems in the workplace, and therefore, the reforms in the Japanese enterprises might be a help and could pave the way in solving those problems.

\section{References}

Asao, Y. (2011). Overview of Non-regular Employment in Japan. Retrieved from https://www.jil.go.jp/english/reports/d ocuments/jilpt-reports/no.10_japan.pdf

CNBC. (2018, December 12). Japan opens the door to more foreigners. That may not solve its labor woes. Retrieved January 26, 2019, from CNBC website:

https://www.cnbc.com/2018/12/13/jap an-economy-labor-shortage-shinzoabe-bets-on-foreigner-workers.html

Gender Equality Bureau of Japan. (2017). Gender Equality Policy in Japan. Retrieved from https://www.gender.go.jp/international /int_kaigi/int_acw3/pdf/contry_present ation_japan_09.pdf

JapanGov. (2019). Abenomics: For future growth, for future generations, and for a future Japan. Retrieved March 17, 2019, from https://www.japan.go.jp/abenomics/_u serdata/abenomics/pdf/1901_abenomi cs.pdf

Kameda, N. (2013). Japanese Global Companies: The Shift from Multinationals to Multiculturals. Global Advances in Business Communication, 2(1), 1-18.
Keidanren. (2017). Charter of Corporate Behavior. Retrieved from http://www.keidanren.or.jp/en/policy/c sr/charter2017.pdf

Liu-Farrer, G. (2011). Making Careers in the Occupational Niche: Chinese Students in Corporate Japan's Transnational Business. Journal of Ethnic and Migration Studies, 37(5), 785-803. https://doi.org/10.1080/1369183X.201 1.559718

MHLW. (2018). Japan's Labor Market (1990-2018).

Ministry of Internal Affairs and Communications of Japan. (2017). Hatarakujosei no jōkyō (Situation of working women). Retrieved from https://www.mhlw.go.jp/bunya/koyou kintou/josei-jitsujo/dl/17b.pdf

MOJ. (2018). Points-based System for Highly-Skilled Foreign Professionals. Retrieved July 23, 2018, from http://www.immimoj.go.jp/newimmiact_3/en/system/in dex.html

Moriya, T. (2012). Nihon kigyō no ryūgakusē nado no gaikokujin saiyō he no kōsatsu (Investigation of the recruitment of international students into Japanese firms). Japanese Labor Studies, 623, 29-36.

Nagatomo, J. (2014). Migration As Transnational Leisure: The Japanese Lifestyle Migrants in Australia. Brill.

Nakamura, J. (2010). Impacts of International Migration on the Labor Market in Japan. Japan Labor Review, 7(3), 68-85.

Nikkei Asian Review. (2018). Japan approves 126 measures to attract more foreign workers. Retrieved December 26, 2018, from Nikkei Asian Review 
website:

https://asia.nikkei.com/Spotlight/Japan -Immigration/Japan-approves-126measures-to-attract-more-foreignworkers

Oishi, N. (2012). The Limits of Immigration Policies: The Challenges of Highly Skilled Migration in Japan. American Behavioral Scientist. https://doi.org/10.1177/000276421244 1787

Prime Minister of Japan and His Cabinet. (2016). The Japan's Plan for Dynamic Engagement of All Citizens. Retrieved from https://www.kantei.go.jp/jp/singi/ichio kusoukatsuyaku/pdf/plan2.pdf

Prime Minister of Japan and His Cabinet. (2018). Mirai Tōshi Senryaku 2018
(Future Investment Strategy 2018).

Tokyo: Cabinet Office.

The Associated Press. (2018, December 8).

Japan Japan OKs divisive bill

allowing more foreign workers.

Retrieved January 26, 2019, from The

Associated Press website:

https://www.apnews.com/f312b64eeaf 2402d8f85733c35ce41bc

The Wall Street Journal. (2018). Japan to Accept More Foreign Workers in a Break From Its Historical Stance. Retrieved January 26, 2019, from https://www.wsj.com/articles/japan-toaccept-more-foreign-workers-in-abreak-from-its-historical-stance1544215014 